\title{
Obama, Trump and Indian foreign policy under Modi
}

\author{
Šumit Ganguly ${ }^{1}$
}

Published online: 20 March 2021

○) The Author(s), under exclusive licence to Springer Nature Limited 2021

\begin{abstract}
This paper traces the evolution of Indian foreign policy during the two terms of the Obama presidency followed by that of Trump. It argues that that a substantial degree of policy continuity has persisted despite changes in administration in the United States.
\end{abstract}

Keywords United States $\cdot$ India $\cdot$ Foreign policy $\cdot$ Security $\cdot$ History

\section{Introduction}

\section{The past as prologue}

During much of the Cold War, Indo-US relations, except during a set of critical junctures, were mostly bereft of substance. Though in the pre-independence era the United States and India had had extensive cultural and commercial ties, these did not carry over into the post-independence era (Slate 2019). The palimpsest of the past did not endure as India self-consciously steered clear of any strategic involvement with the United States. In the economic realm, it was focused on a strategy of import-substituting industrialization (ISI) coupled with an emphasis on economic autarky. These policies, quite understandably, did little to attract American trade or investment. Despite the lack of significant material interests in India and South Asia, until about the mid-1960s the US did make a concerted attempt to aid India in a variety of ways, especially with food assistance, in large part because of its own Cold War imperatives (Merrill 2010). However, thereafter, especially following the second Indo-Pakistani conflict in 1965, its attention mostly shifted toward Southeast Asia and the conduct of the Vietnam War. Consequently, any further American involvement in the country was spasmodic and mostly derivative of overarching American global interests (Chaudhuri 2013). Despite the usual pieties about

Šumit Ganguly

sganguly@indiana.edu

1 Department of Political Science, College of Arts and Sciences, Indiana University Bloomington, 107 S. Indiana Avenue, Bloomington, IN 47405-7000, USA 
shared democratic values that national leaders in both countries routinely alluded to, the two countries mostly found themselves at odds during the Cold War.

Even after the end of the Cold War, given the paucity of links between the two countries, questions pertaining to nonproliferation and human rights still dominated the Indo-US bilateral relationship. The real beginnings of a thaw in relations came only after India faced an unprecedented fiscal crisis in 1991. Faced with the prospect of major loan defaults to a range of international lenders, India undertook a series of major liberal economic reforms in the wake of the crisis. These reforms significantly opened up the Indian market to foreign (and especially American) investment, prompted rapid economic growth and led to a significant reduction in both rural and urban poverty.

Simultaneously, around this time there was also a major reorientation of India's foreign policy. With the demise of the Soviet Union, the country no longer enjoyed the support of a veto-wielding power in the United Nations Security Council. Also, the highly attractive arms transfer relationship that had existed with the Soviet Union abruptly drew to a close. The principal successor state, Russia, evinced little interest in sustaining the same strategic and military relationship that India had enjoyed during the Soviet era. Under these circumstances, and especially confronted with a rising China, India could hardly afford to keep the sole surviving superpower, the United States, at an arm's length. Both these factors created conducive conditions for a rapprochement with the United States (Kapur and Ganguly 2007).

Nevertheless, irritants within the relationship remained. In considerable part, they were legacy issues stemming from the Cold War years. Since the two sides had been at odds for so long, Indian elites remained deeply distrustful of the United States. Ironically, it was the Indian nuclear tests of May 1998 that prompted a serious dialogue between the two countries (Talbott 2006). In the wake of the tests, extensive bilateral discussions ensued and US policymakers came to pay far greater heed to India and its concerns. Toward the end of the second Clinton administration, despite differences in some critical policy arenas, most notably nonproliferation, the relationship had acquired a degree of meaningful ballast.

The incoming George W. Bush administration, as a consequence, became an important beneficiary of the legacy of the previous government. Even during the election campaign, when spelling out its foreign policy priorities, the Bush campaign had made clear that it would accord a degree of importance to India in its overall foreign policy goals (Rice 2000). It is entirely possible that after assuming office it would have devoted suitable attention to India. However, as a consequence of the terrorist attacks on the United States in September 2001 and its concomitant decision to invade Afghanistan (and then Iraq in 2003), the Bush administration during its first term did not focus on India. Instead its principal concerns in the subcontinent were to maintain Pakistan's fitful support for US war objectives in Afghanistan and to avert an Indo-Pakistani conflict. Given the sheer salience of Pakistan (India's long-standing nettlesome adversary) to its South Asia strategy, the Bush administration perforce had to limit the attention that it devoted to India. It was really in its second term that it tackled one of the most vexing issues in the relationship: India's pursuit of its nuclear weapons program (Ganguly and Mistry 2006). These efforts culminated in the historic US-India civilian nuclear agreement 
of 2008. This accord effectively ended one of the principal issues of contention in the relationship and cleared a pathway for a robust strategic partnership. In the wake of this agreement, and despite much hesitation on India's part, the two sides made fitful progress toward forging a strategic partnership.

Nevertheless, problems in the relationship persisted. Among other matters, India chose to purchase the French Rafale Dassault combat aircraft after spurning an American offer of the F-16, despite considerable lobbying on the part of US officials. Barely six months before Narendra Modi assumed the prime ministership, India's deputy consul-general in New York City, Devyani Khobragade, was arrested for not complying with American labor laws (Ganguly 2015). This episode caused much consternation in New Delhi and prompted various retaliatory actions on its part. At a broader level the US was also unhappy with India's intransigent position on the trade negotiations in the Doha Round. Consequently, when Modi assumed office a number of irritants had crept into the relationship (Tellis 2019).

\section{Indo-US relations under Modi and the Obama administration}

In a most remarkable departure from past precedent, Prime Minister Modi invited President Barack Obama as the Chief Guest to the Republic Day parade in New Delhi in January 2015. While Prime Minister Narasimha Rao had invited President Clinton earlier, Clinton had demurred as it would have conflicted with his State of the Union address (Sitapati 2015). Modi's renewed invitation and Obama's acceptance even at the cost of shifting the State of the Union address signified the extent of the transformation that had taken place in US-India relations.

\section{Personalistic factors}

This article will focus on the personalistic, ideational/national and structural factors that helped shape Indo-US relations during the Obama and Trump administrations. At the outset, it should be underscored that the boost in bilateral relations was somewhat unlikely for at least one compelling reason despite the very substantial progress that had been made in the preceding decade. Specifically, there was little reason for Modi, at a personal level, to try and improve relations with the United States. On the contrary, he had a substantial personal basis for harboring significant misgivings. In 2005, under the terms of the International Religious Freedom Act (IRFA) he was the first foreign dignitary to ever be denied a visa to the United States (Mulford 2005). The US State Department had concluded that "severe violations" of human rights had taken place in the state of Gujarat in February 2002 when he was the Chief Minister, when several hundred Muslims had been killed in what appeared to be a pogrom.

Yet, about a decade later, when Modi assumed office in 2014, the US adopted a markedly different stance. Senior US officials argued that the Indian Supreme Court had concluded that there was inadequate evidence to link Modi to the events of February 2002, that he had won an election that was widely seen as free and fair and was 
the now the principal elected representative in the country. Accordingly, there were no grounds to deny him a visa again (personal interview, 2005). If Modi had harbored any resentment over the denial of the visa it was certainly not apparent from his public remarks. Indeed, within months of assuming office, he was accorded a state visit to the United States in September 2014. More to the point, significant segments of the Indian diaspora ensured that he was greeted with considerable fanfare at a public event held at Madison Square Garden in New York City (Sinha 2014).

When in Washington, DC, during the formal part of the state visit, Modi and Obama managed to forge a personal rapport. Among other matters, Obama, in a spontaneous gesture, took Modi to the Martin Luther King, Jr., Memorial in his presidential limousine. They also published a joint editorial in The Washington Post, which characterized the partnership as "robust, reliable and enduring" (Hall 2019: 7).

From Modi's standpoint, this visit clearly marked his rehabilitation in the United States. It also revealed an evidently pragmatic streak to his personality: despite the obvious humiliation of having been denied a visa in 2005 , he did not allow the episode to hobble a rapprochement with the United States. In fact, it has been argued that Modi placed considerable stock in cultivating warm, personal relations with the leaders of states whose interests coincided with those of India. There was a clear-cut logic to this strategy. If interests converged, then cordial personal ties could help boost them. If they were dissonant, then the rapport between the leaders could help assuage concerns (Tellis 2019).

In turn, despite President Obama's professed concern about human rights issues, unlike that of his predecessor, his administration also found it expedient to accommodate Modi after he assumed office (Sammon 2020). Shortly after Modi's electoral victory in April 2014, Obama had personally called him to congratulate him. This was not entirely surprising. Despite its soaring rhetoric on human rights, the Obama administration on many occasions had backed away from adopting an unyielding stance when other compelling foreign and security considerations proved to be at stake (Power 2019). Indeed, it was only toward the end of his second term in office when on a second state visit to India that Obama, in a public speech in Bombay (Mumbai), drew attention to the increasingly hostile climate for minorities under Modi (Roberts and Burke 2015). Unfortunately, as a number of Indian commentators underscored, Obama undercut his own message with a visit to Saudi Arabia on his way home. In Saudi Arabia, he maintained a deafening silence on that country's extremely dubious record on human rights.

Other key members of his Cabinet also mirrored and carried forward the President's agenda with India. The most notable of them, of course, was the Secretary of Defense, Ashton Carter. Even before he assumed the position of Defense Secretary, it was evident that Carter had recognized the strategic significance of India. He had as the Deputy Secretary of Defense overseen the implementation of the Defense Technology and Trade Initiative (DTTI). The DTTI was designed to ease various bureaucratic and other obstacles to enhanced defense cooperation with India (Joshi 2014). Subsequently, Carter played an important role in the revival of the DTTI and also led efforts to upgrade the trilateral military exercise Malabar (Hall 2019: 138). 
As the Secretary of Defense, Carter visited India multiple times and helped create the India Rapid Reaction Cell designed to expedite defense sales to India (Pant 2016). Among other matters, after over a decade of negotiations, the two sides also signed the Logistics Exchange Memorandum of Agreement (LEMOA) in the waning days of the Obama administration (Basrur 2017). Under the terms of this accord, the two countries would have access to each other's designated military facilities for the purposes of refueling and replenishment. It would also ease port calls, training and joint humanitarian and disaster relief efforts (Peri 2016). While the United States had this agreement in place with any number of other states, reaching it with India was no minor accomplishment. It had long been hobbled because of deepseated misgivings in the Indian defense bureaucracy about an overly close working relationship with the United States. This was especially the case during the two UPA governments when A.K. Antony was the Minister of Defense (Unnithan 2014; Tellis 2019).

\section{Ideational/national factors}

Any improvement in relations with the US under the Obama administration could not have taken place were it not for a marked absence of the reflexive anti-Americanism within the Bharatiya Janata Party (BJP) in marked contrast to its pervasive presence with in the Indian National Congress. Some resentment did exist within the BJP about the US's willingness to overlook Pakistan's continued dalliance with terror directed at India (personal interview 2002). However, there was also an understanding that the US's reluctance to confront Pakistan stemmed from the continued American reliance on Pakistan to prosecute the war against the Taliban and the remnants of Al Qaeda in Afghanistan. Accordingly, despite their misgivings, the BJP government under Modi decided to set them aside, adopting a very matter-of-fact approach in its dealings with the United States.

On the American side, the Obama administration had also significantly benefited from the transformation of US-Indian relations that had come about under President George W. Bush. Perhaps the most striking achievement of the Bush administration had been the consummation of the US-India civilian nuclear accord of 2008.

The US, in turn, has long faced a fundamental tension in balancing ideals and self-interest in the conduct of its foreign policy (Osgood 1963). Public professions aside, all too often, in most hard cases, the US has set aside ethical and moral considerations when important material interests were at stake. Even the administration of President Jimmy Carter, which had made a public commitment to the promotion of human rights on a global basis, backed away when it perceived that critical national security interests could be involved (Vogelgesang 1980). The issue also appeared to have dogged the Obama administration despite having a senior official who was passionately committed to the question (Power 2019).

Consequently, it is not entirely surprising that the Obama administration also set aside its reservations once Modi assumed the helm of affairs in India. India's growing market and its potential as a balancer to the People's Republic of China (PRC) in Asia both played a role in shaping the administration's calculations. While 
there were a handful of dissenting voices in Congress, for the most part there was no groundswell of opposition within the legislative body that stood in the way of the administration's decision to work with the Modi government.

Finally, on the basis of inference and attribution, it can be reasonably argued that Obama was not oblivious to the growing political significance of the Indian diaspora. This factor, no doubt, also played a role in shaping policy toward India. In fact, far from ignoring the diaspora, the administration reached out to crucial segments thereof to bolster ties with India, especially to boost flagging economic ties (Roberts 2015).

Despite all these factors, the Obama administration made a significant misstep in its initial days in terms of relations with India. Keen on bringing the involvement in Afghanistan to a close it appointed Richard Holbrooke, a veteran diplomat and negotiator, as the Special Representative for Afghanistan and Pakistan (Colley and Ganguly 2020). Perhaps as a consequence of deft Pakistani lobbying Holbrooke initially sought to include the Kashmir dispute as part of his portfolio (Jha 2009). But when this became public knowledge India mounted a forceful diplomatic campaign to ensure that the Kashmir dispute would not be on his agenda. Faced with strenuous objections from India the White House, despite Holbrooke's preferences, chose to keep India outside the ambit of his duties (Rozen 2009). Nevertheless, in the first six months of the administration India was not given any particular significance in the administration's foreign policy priorities.

Once Modi assumed office in May 2014, an important legacy issue quickly came to the fore in Indo-US relations. This involved long-standing US frustrations with India's intellectual property protection regime. The US had complained for some time that India's commitment to the protection of intellectual property rights had left much to be desired. As a consequence, in 2014 the office of the United States Trade Representative (USTR) had placed India on its priority "watch list" and had scheduled an Out-of-Cycle review for later in the year. No doubt as a consequence of this impending review, the Modi government set up a working group to address this issue. The actions that India undertook evidently satisfied the USTR because it closed the matter in December of 2014 (Hindustan Times Correspondent 2014).

In June 2015, Modi went on a state visit to the United States. This visit, quite apart from the surrounding fanfare, much of which had involved the diaspora community in the United States, yielded a number of highly substantive results. In a statement that the White House released during his visit it declared India to be a "possible anchor of stability". Most importantly, the US also announced that India would be designated as a "major defense partner". Under its terms, India would now be granted license-free access to a wide range of dual-use technologies from the United States. In turn, India also committed itself to strengthening its export control regime (Gould 2016). The declaration of India as a "major defense partner" was a landmark development in US-India relations because India's quest for access to dual-use technologies had long been denied.

Many of these shifts were also possible because Modi had effectively abandoned India's hoary commitment to nonalignment. The two United Progressive Alliance (UPA) regimes that preceded Modi's government, while not routinely alluding to nonalignment, had nevertheless dwelt on the concept of "strategic autonomy" as a 
guiding principle in their foreign and security policies. In many ways, this term was little more than a euphemism for nonalignment as it emphasized India's reflexive hostility toward entering anything resembling an alliance. Of course, this stance was utterly ahistorical — during much of the Cold War India had been acutely dependent on the Soviet Union and was, for all practical purposes, tacitly aligned with it on a range of issues (Ganguly 2019a, b). Instead of the continuing dalliance with nonalignment, Modi's Foreign Secretary, Subrahmanyam Jaishankar, introduced the term "leading power" as opposed to a mere balancing power (Jaishankar 2015).

\section{Structural factors}

Perhaps the most important force that led the Obama administration to reach out to India was structural. By its second term, the administration had concluded that a rapprochement with the PRC was simply not in the cards. Its initial efforts to try and accommodate the PRC and to weave it into the norms and institutions of a USshaped global order had not materialized. As a consequence, the administration had recalibrated its views and had come to see China as a strategic competitor to the United States. Once it arrived at this conclusion finding a possible pathway to balance the growing power and assertiveness of the PRC in Asia became a virtual strategic necessity.

After having fitfully attempted to improve relations with India, the administration made a clear-cut decision to court India. The decision to focus attention on India was straightforward: it was, after all, the only land power of any consequence that could serve as a possible strategic bulwark against an increasingly assertive PRC. More to the point, confronted with an on-going border dispute, it lacked the requisite domestic wherewithal to cope with the challenge from the PRC. Consequently, it had a significant incentive, despite misgivings about past American unreliability, to turn toward the United States.

The first noticeable shift in the Obama administration's policy toward India was signaled with Secretary of State Hilary Clinton's visit to India in July 2009. During this visit, the two sides made significant progress on defense and civilian nuclear issues. Also, it was notable for the initiation of a "strategic dialogue" between the two foreign policy bureaucracies (Agencies 2010).

Her visit to India, in effect, paved the way for Prime Minister Manmohan Singh's state visit to the United States. During that visit, in November 2009, President Obama declared India and the United States to be "natural allies" (Whitelaw 2009). Subsequently, in December 2010, during his first state visit to India, Obama delighted his hosts in a speech to the Indian parliament when he suggested a US willingness to eventually support India's bid for a seat on the United Nations Security Council (UNSC). Since a permanent seat on the UNSC was a long-standing goal of Indian policymakers, this signal from the President of the United States was seen as a major, positive development in US-India relations (Stolberg and Yardley 2010).

The most significant turning point in the relationship, however, came in November 2011 when the administration announced its rebalancing strategy and spelled out 
India's role in it. Pared to the bone, the "rebalancing" strategy involved an expansion of the US presence in the southwestern Pacific and was designed to make it more flexible. More specifically, it called for new deployments or rotations of troops and equipment to Australia and Singapore (Manyin et al. 2012). Some observers argued that the "rebalancing" strategy could prove be a useful complement to India's "Look East" policy that had been unveiled some years earlier, which was focused on engaging the states of Southeast Asia on a number of different fronts (Burgess 2015).

Finally, before the Obama administration came to a close Modi's government took a remarkably bold step in terms of aligning India's interests with those of the United States in the Indo-Pacific. This was codified in a joint statement entitled "US-India Joint Strategic Vision for the Asia Pacific and the Indian Ocean Region". This document not only reaffirmed India's commitment to the freedom of navigation and overflight in the contested South China Sea but most importantly spelled out its willingness to play a significant role in the region to ensure peace and prosperity (Tellis 2019). Consequently, when the Obama administration left office, the IndoUS relationship was, for the most part, on an even keel. Matters would undergo a change, however, when the Trump administration assumed office in 2016. The principal reason for this shift can be attributed to the new president's world view, which departed from a focus on issues of long-term strategy and instead saw foreign policy issues in strictly transactional terms.

\section{Trump and the future of the relationship: beliefs and personal predilections}

There is little or no question that the Trump administration evinced considerable hostility toward the foreign policy legacies of the Obama era. Though Trump did not view India with hostility, he nevertheless appeared inclined to confront India in a more strident fashion on some matters that he deemed important. To that end, he quickly seized upon issues of market access, trade and H1-B visas. In the background also was India's relationship with Iran, a country toward which Trump was openly hostile. Despite his predilections his initial Secretary of Defense, James Mattis, as well as his Secretary of State, Rex Tillerson, recognized the strategic significance of India. Consequently, their stances toward India ensured a degree of continuity in policies.

Mattis, from his early days in office, ensured that India remained a priority in US strategic calculations. In September 2017, he made his initial trip to India in his capacity as the Defense Secretary. When in the country he made it abundantly clear that the US attached considerable significance to the bilateral security partnership. Among other matters, the two sides agreed to boost maritime security cooperation and enhance technology sharing. Probably in a thinly veiled reference to Pakistan, Mattis also underscored the US commitment to ending terrorist safe havens. His visit, the first of a Trump Cabinet-level official to India, signaled a remarkable policy continuity under the new administration. Most importantly, during his visit he declared that India was a "pillar of regional stability and security" (Roche 2017). 
Mattis, of course, was not the only key individual in the upper realms of foreign and security policy to recognize the significance of India. Trump's first Secretary of State, Rex Tillerson, also indicated early in his tenure the importance that his department attached to India. Shortly before his first visit to region in October 2017, at a speech at the Center for Strategic and International Studies, a prominent think tank in Washington, DC, Tillerson spelled out his views about India, China and Pakistan. He hailed the relationship with India, argued that the PRC represented a threat to world order and asserted that Pakistan needed to do more to combat terrorism (Harris 2017).

In turn, on the Indian side both Prime Minister Modi and Foreign Secretary (and subsequently Minister for External Affairs) Subrahmanyam Jaishankar were astute enough to be able to deal with the possible vagaries of a highly mercurial president. Not surprisingly, after Trump's inauguration Modi made a concerted effort to court him. Even before Trump formally assumed office Indian officials had reached out to the transition team. Consequently, when Modi visited the United States in June 2017, he was more than aware that a very different political landscape awaited him in Washington, DC (Madan 2017). Fortunately, this meeting helped place the Indo-US relationship on a more secure footing. Specifically, the two leaders found common ground in three distinct areas: maritime security, counterterrorism and defense. That said, two lingering and troubling questions remained. The first dealt with Trump's "America First" approach to most foreign policy issues. The second, equally predictably, dealt with the trade deficit with India, one of Trump's personal obsessions based upon his belief that far too many trading partners had long exploited the United States (Desai 2017).

These areas of convergence and dissonance aside, Trump's personality had a distinct impact on the evolution of relations with India. His faith in personal diplomacy twice led him to make remarks which were not only unwelcome in India but also revealed his lack of sensitivity toward complex and vexed issues. The first instance occurred following his meeting with President Imran Khan of Pakistan in July 2019. Following this meeting, Trump announced that he was ready, willing and able to mediate the long-running dispute over Kashmir between India and Pakistan (Hick and Fredericks 2019). Despite India's sharp reaction to this suggestion, Trump nevertheless reiterated the offer in September 2019 following a second meeting with Khan. He even suggested that he would deserve the Nobel Peace Prize should he succeed in contributing to such a resolution (Hick and Fredericks 2019). Quite predictably, India again rebuffed any such initiative. His naivete and lack of knowledge of vexed issues on the subcontinent were once again on display in May 2020 when he announced his willingness to mediate the Sino-Indian border conflict in the aftermath of a series of clashes earlier in the month (Kazmin 2020).

Trump's vagaries aside, key individuals within his administration understood the need for policy continuity and avoided making any statements that departed dramatically from long-established precedents. Accordingly, after Tillerson was ousted from office, his successor, Mike Pompeo, sought to sustain the Indo-US relationship. For example, when he traveled with his counterpart from the Department of Defense, James Mattis, to India in September 2018 for the "two plus two" talks, which involved the highest foreign and security officials of the two countries, he 
was keen on smoothing over the rough edges in the relationship (Harris 2018). When they met with their Indian counterparts, Nirmala Sitharaman (the Minister of Defense) and Sushma Swaraj (the Minister for External Affairs), they focused their attention on enhancing defense cooperation and ensuring an open Indo-Pacific. Even though differences remained over India's reliance on Iran for petroleum and its plans to purchase the S-400 missile system from Russia, these were not allowed to disturb the overall positive tenor of the talks (PTI 2018).

The second "two plus two dialogue" that was held in Washington, DC in December 2019 proved to be quite productive (Raj 2019). On this occasion, two new individuals were at the helm of the Indian delegation. Subrahmanyam Jaishankar was now the new Minister for External Affairs. Nirmala Sitharaman had been shifted to the Finance Ministry and the erstwhile Minister for Home Affairs, Rajnath Singh, had now taken charge of the Ministry of Defense. Among other matters, the two sides signed the Industrial Security Annex (ISA). Under the aegis of this agreement Indian private-sector companies would be able to co-develop sensitive technologies with their American counterparts. Additionally, they also tackled one of India's principal concerns, namely Pakistan's continuing involvement with terror. The success of this meeting underscored that despite changes in key personnel on the Indian side substantial policy continuity prevailed.

That said, the dialogue did not include certain issues that had loomed large during the Obama administration. For example, the prior focus on cooperation on clean energy and climate change was absent in these discussions. The lack of these agenda items was hardly surprising: Trump had made it abundantly clear that he had little or no interest in addressing the issue of global climate change. Nor, for that matter, did these talks include questions of trade and investment. Those issues were relegated to the office of the United States Trade Representative.

\section{An ideational shift}

The advent of the Trump administration had also highlighted a significant ideational shift in American foreign-policy priorities. Though the Obama administration had failed to live up to its lofty rhetoric on human rights, it had nevertheless made more than a nod to those concerns. The new administration, however, evinced scant interest in the subject except to use the issue in strictly instrumental terms. For example, as the trade talks with the PRC reached a virtual deadlock and the administration sought to deflect blame for its abject handling of the Covid-19 pandemic, Secretary of State Mike Pompeo made the issue of a controversial Chinese law that would effectively stifle dissent in Hong Kong a centerpiece of his concerns. Among other matters, he threatened to end the special status that had long been accorded to Hong Kong on trade and other related issues (Crowley et al. 2020).

It needs to be noted in this context that the same administration had done little to sanction Saudi Arabia after ample evidence of the state's complicity in the murder of a well-known Saudi dissent and commentator, Jamal Khashoggi, at the Saudi consulate in Istanbul in December 2018 (McKernan 2019). On the contrary, the 
administration had largely turned its back on his killing and the subsequent rationalizations of the regime about his assassination (Hubbard 2020).

Consequently, it is hardly surprising that when it came to questions of the state of human rights in India, he proved more than willing to give it a pass. The issue arose against a backdrop of a series of highly discriminatory policies that the Modi government had instituted against the country's substantial Muslim minority after coming to office a second time in 2016 (Ganguly 2019a, b). Trump, during his state visit to India in February 2020, refused to condemn those policies (Stokes and Bierman 2020).

On other issues, however, differences with India persisted owing to unresolved matters from the past as well as Trump's personal stance on trade disputes. Convinced that a number of countries had been treating the United States unfairly in trade issues, Trump had made reorienting the terms of trade one of his key campaign issues. Even though the US trade deficit with India was hardly substantial, he nevertheless chose to berate India about the matter. To that end, he placed tariffs on Indian steel and aluminum imports, leading India to impose retaliatory tariffs on various American food products including almonds and apples (Rajghatta 2019). Worse still, the administration withdrew the privileges accorded to India under the aegis of the Generalized System of Preferences (GSP) (Lakshman 2019). This decision was hardly propitious for promoting a trade deal with India. Not surprisingly, despite hopes that a trade deal would be accomplished during his visit to India in 2020, it eventually failed to materialize.

\section{The persistence of structural imperatives}

Regardless of differences on certain issues there is little or no question that a common structural imperative, the rise and assertiveness of the PRC, continued to cement relations between the two countries. It is true that the US failed to take an unequivocal stance during the 2017 Doklam crisis near the Bhutan, China and India trijunction when a contingent of Chinese military troops at started to build a road in contested territory. At Bhutan's instance, India had promptly moved troops to confront the Chinese. The Trump administration, preoccupied with a number of domestic issues, failed to forthrightly support India (Lynch 2017).

Its stance toward another border clash in 2020, in the region of Ladakh, however, proved to be markedly different. On this occasion, the Principal Assistant Secretary of State for Central and South Asia, Alice Wells, in a May 2020 speech at the Atlantic Council, a think tank in Washington, DC, had made it abundantly clear that the administration saw the PRC as the aggressor (Wells 2020). Earlier in the year, the administration had also signaled its support for India when the US ambassador to India, Kenneth Juster, had visited Tawang in the state of Arunachal Pradesh to attend an annual festival. The visit was fraught with considerable significance as the PRC considers the region to be disputed territory. 
More to the point, the State Department made it abundantly clear that his visit signified American support for India's sovereignty (PTI 2019).

\section{Conclusions}

By the time Obama left office in 2017, the US-India relationship was on a substantially more secure footing despite the minor admonition about growing religious intolerance that he had delivered in a valedictory speech in India. The deepening of this relationship had come about despite the markedly different ideological stances of the two national leaders. Obama during his two terms in office had sought, albeit imperfectly, to renew an American commitment to human rights on a global basis. Modi, on the other hand, had remained almost entirely unapologetic about his record on human rights during his tenure as the Chief Minister of Gujarat. These considerations, while not unimportant in American foreign policy, were nevertheless balanced against other, more compelling material and structural issues.

Consequently, despite these lingering concerns, the two leaders took significant strides in their bilateral relationship during their overlapping terms in office. In considerable part, the deepening that came about in the relationship stemmed from national and structural imperatives. In the United States, a very substantial segment of the Indian diaspora was well-disposed toward Modi and made no secret of its interest in boosting the US-India relationship. Apart from a small, if vocal, segment of the community, for the most part it was not concerned about, or was prepared to overlook, his human rights record. Furthermore, for the US business community, India still held out the promise of an important market for American products as well as investment. Both of these domestic-level factors contributed to the sustenance of a relationship that had gathered some real momentum in the past decade.

The most important factor, however, that contributed to the strengthening of the relationship was structural. In the initial months of Obama's first term he had evinced scant interest in India as he had sought to deal with the financial crisis at home and focused his attention on winding down two unpopular wars abroad. He had also devoted much effort toward forging a working relationship with the People's Republic of China. However, this effort had run aground during his visit to Beijing in November 2009 (Demick 2009). Also, the PRC's growing assertiveness in Asia and especially in the South China Sea had also contributed to US misgivings about its behavior. Both these factors had led the administration to reassess its view of the PRC and had thereby prompted the turn toward India.

The Trump administration, despite its seemingly reflexive hostility toward most features of Obama's foreign and security policies, for the most part continued the trajectory of engagement with India. At the outset both Secretary of Defense James Mattis and Secretary of State Rex Tillerson signaled the administration's interest in sustaining the momentum that had gathered under the Obama administration. Subsequently, despite some minor hiccups, Modi and Trump seemed to find a degree of personal rapport. As populist leaders with authoritarian leanings 
and a shared distrust of Islam and the Muslim world it is hardly surprising that they could find common ground.

The problems that arose in the relationship, in considerable measure, stemmed from Trump's transactional approach to foreign policy questions as well as his idiosyncratic decision-making style (Rucker and Leonnig 2020). Despite his mercurial choices, a small handful of key officials recognized the significance of India and for the most part managed to maintain a viable working relationship.

Personalities certainly have played an important role in sustaining the momentum in the relationship. However, in the absence of a convergence of structural interests it is doubtful that the relationship would still be moving forward. The US misgivings about the PRC, which in growing measure are shared in India, have played a critical role in ensuring that the United States and India continue to work together to sustain the strategic partnership despite continuing wrangling over some issues.

\section{Compliance with ethical standards}

Conflict of interest On behalf of all authors, the corresponding author states that there is no conflict of interest.

\section{References}

Agencies. 2010. First US-India Strategic Dialogue from June 1-4. The Indian Express.

Basrur, Rajesh. 2017. Modi's foreign policy fundamentals: a trajectory unchanged. International Affairs 93 (1): 7-26.

Burgess, Stephen. 2015. The US pivot to Asia and the renewal of the US-India strategic partnership. Comparative Strategy 34 (4): 367-379.

Chaudhuri, Rudra. 2013. Forged in Crisis: India and the United States Since 1947. London: C Hurst and Compan.

Colley, Christopher K. and Sumit Ganguly. 2020. "The Obama Administration and India." In The US in the Indo-Pacific: Obama's Legacy and the Trump Transition, eds. Oliver Turner and Inderjeet Parmar, 44-62. Manchester: Manchester University Press.

Crowley, Michael, Edward Wong and Ana Swanson. 2020. Rebuking China, Trump curtails ties to Hong Kong and severs them with WHO. The New York Times, 15 July.

Demick, Barbara. 2009. China not in a gift-giving mood, The Los Angeles Times, 18 November.

Desai, Ronak D. 2017. “Three Key Takeaways from Modi and Trump's First Meeting,” Forbes.com, July 6. https://www.forbes.com/sites/ronakdesai/2017/07/06/three-key-takeaways-from-modiand-trumps-first-meeting/\#eefa59311435.

Ganguly, Sumit. 2015. Indian Foreign Policy: A Short Introduction. New Delhi: Oxford University Press.

Ganguly, Sumit. 2019a. The United States can't solve the Kashmir Dispute. ForeignAfffairs.com,30 July. https://www.foreignaffairs.com/articles/india/2019-07-30/united-states-cantsolve-kashmir-dispute.

Ganguly, Sumit. 2019b. Secularism is Dying in India. ForeignPolicy.com, December 11. https://forei gnpolicy.com/2019/12/11/secularism-is-dying-in-india/.

Ganguly, S., and Dinshaw Mistry. 2006. The case for the US-India nuclear agreement. World Policy Journal 23 (2): 11-19.

Gould, Joe. 2016. “US Names India 'Major Defense Partner,” DefenseNews.com. June 7. https://www. defensenews.com/home/2016/06/07/us-names-india-major-defense-partner/.

Hall, Ian. 2019. Modi and the Reinvention of Indian Foreign Policy. Bristol: University of Bristol Press. 
Harris, Gardiner. 2017. “Tillerson Hails Ties with India But Criticizes China and Pakistan. The New York Times, 28 October.

Harris, Gardiner. 2018. "Trumps' rough edges Complicates Trip by Pompeo and Mattis to India. The New York Times, 8 September.

Hick, Nolan and Bob Fredericks. 2019. Trump offers to mediate Kashmir dispute between Pakistan, India. The New York Post, 23 September.

Hindustan Times Correspondent. 2014. US closes out-of-cycle review of India's trade and patent policies. The Hindustan Times, 14 December.

Hubbard, Ben. 2020. MBS: The Rise to Power of Mohammed bin Salman. New York: Duggan Books.

Jaishankar, Subrahmanyam. 2015. IISS Fullerton Lecture, Singapore, July 20. https://www.mea.gov.in/ Speeches-Statements.htm?dtl/25493/iiss+fullerton+lecture+by+dr+s+jaishankar+foreign+secre tary+in+singapore.

Jha, Lalit K. 2009. Holbrook portfolio includes India: Petraeus. OutlookIndia.com, 25 April. https:// www.outlookindia.com/newswire/story/holbrooks-portfolio-includes-indiapetraeus/658893.

Joshi, Shashank. 2014. Why India really Likes Ashton Carter. The National Interest.com, December 4. https://nationalinterest.org/blog/the-buzz/why-india-really-likes-ashton-carter-11787.

Kapur, Paul S., and Sumit Ganguly. 2007. The transformation of US-Indian relations: an explanation for the rapprochement and prospects for the future. Asian Survey 47 (4): 642-656.

Kazmin, Amy. 2020. Donald Trump offers to mediate in India-China Dispute. Financial Times, May 27.

Lakshman, Sriram. 2019. US President Trump terminates preferential trade status for India under GSP. The Hindu, 1 June.

Lynch III, F. Thomas. 2017. "A Failure of Strategic Vision: US Policy and the Doklam Border Dispute," Strategic Insights, Institute for National Strategic Studies, National Defense University, 6 September. https://inss.ndu.edu/news/Article/1428958/a-failure-of-strategic-vision-us-policy-and-thedoklam-border-dispute/.

Madan, Tanvi. 2017. When Modi meets Trump: where do US-India relations stand? The Brookings Institution, 23 June. https://www.brookings.edu/blog/order-from-chaos/2017/06/23/when-modi-meetstrump-where-do-u-s-india-relations-stand/.

Manyin, Mark E., Stephen Daggett, Ben Dolven, Susan V. Lawrence, Michael F. O'Rourke Martin, and Ronald Vaughn Bruce. 2012. Pivot to the Pacific? The Obama Administration's "Rebalancing” Toward Asia. Washington, DC: Congressional Research Service.

McKernan, Bethan. 2019. Jamal Khashoggi Murder: Timeline of Key Events. The Guardian, 23 December.

Merrill, Dennis. 2010. Bread and Ballot The United States and India's Economic Development. Chapel Hill: University of North Carolina Press.

Mulford, David C. 2005. "Issue of Gujrat Chief Minister Narendra Modi's Visa Status," U.S. Department of State, New Delhi, 21 March. https://2001-2009.state.gov/p/sca/rls/rm/2005/43701.htm

Osgood, Robert. 1963. Ideals and Self-Interest in America's Foreign Relations. Chicago: University of Chicago Press.

Pant, Harsh V. 2016. Ash Carter comes calling: where do US-India defense ties go from here? The Diplomat, 26 April. https://thediplomat.com/2016/04/ash-carter-comes-calling-wheredo-us-india-defen se-ties-go-from-here/.

Peri, Dinakar (2016) What is LEMOA? The Hindu, 30 August.

Power, Samantha. 2019. The Education of an Idealist: A Memoir. New York: HarperCollins.

Press Trust of India. 2018. India, US hold inaugural edition of $2+2$ strategic talks, discuss range of issues. The New Indian Express, 6 September.

Press Trust of India. 2019. Envoy's visit to Tawang highlights support for Indian sovereignty: US. Business Standard, 1 November.

Raj, Yashwant. 2019. India. US sign key defense pact, discuss cross-border terror at $2+2$ meet. The Hindustan Times, 19 December.

Rajghatta, Chidanand. 2019. Trump's tariff rant at India presages more trade troubles with US. The Times of India, 9 July.

Rice, Condolezza. 2000. Campaign 2000: Promoting the National Interest. Foreign Affairs, January/ February.

Roberts, Dan. 2015. Obama enlists help of Indian diaspora to bolster stronger economic ties. The Guardian, 26 January.

Roberts, Dan, and Jason Burke. 2015. Barack Obama challenges India on religious tolerance and human rights. The Guardian, 27 January. 
Roche, Elizabeth. 2017. James Mattis in India: US commits to transfer advanced defense technology for Make in India. Livemint.com, 26 September. https://www.livemint.com/Politics/07dee1V8Wt cWlYPFcFeslM/US-commits-to-transfer-advanced-defence-technology-for-Make.html.

Rozen, Laura. 2009. India's stealth lobbying against Holbrooke's brief. ForeignPolicy.com, 24 January. https://foreignpolicy.com/2009/01/24/indias-stealth-lobbying-against-holbrookes-brief/.

Rucker, Philip, and Carol Leonnig. 2020. A Very Stable Genius: Donald J. Trump's Testing of America. New York: Penguin Random House.

Sammon, Alexander. 2020. Barack Obama's legacy is Narendra Modi. The American Prospect, 23 January.

Sinha, Shreeya. 2014. Indian leader Narendra Modi once unloved in the US, gets rock star reception. The New York Times, 27 September.

Sitapati, Vinay. 2015. Half-Lion: How P. V. Narasimha Rao Transformed India. New Delhi: Penguin.

Slate, Nico. 2019. Lord Cornwallis is Dead: The Struggle for Democracy in the United States and India. Cambridge: Harvard University Press.

Stokes, Eli and Noah Bierman. 2020. Trump declines to condemn India's anti-Muslim law. The Los Angeles Times, 25 February.

Stolberg, Sheryl Gay, and Jim Yardley. 2010. Obama supports UN seat for India. The New York Times, 8 November.

Talbott, Strobe. 2006. Engaging India: Diplomacy, Democracy and the Bomb. Washington, DC: Brookings Institution Press.

Tellis, Ashley J. 2019. Narendra Modi and US-India relations. In Making a New India: Transformation Under Modi Government, eds. Bibek Debroy, Anirban Ganguly, and Kishore Desai. New Delhi: Wisdom Tree.

Vogelgesang, Sandy. 1980. American Dream, Global Nightmare. New York: WW Norton.

Wells, Alice. 2020. Discussion on India and the Indo-Pacific. Atlantic Council, Washington, DC, 21 May. https://www.state.gov/remarks-and-releases_trashed/discussion-on-india-and-the-indo-pacificatlantic-council/.

Whitelaw, Kevin. 2009. Obama: US, India, 'natural allies' in the 21st century. National Public Radio, 24 November 2009.

Publisher's Note Springer Nature remains neutral with regard to jurisdictional claims in published maps and institutional affiliations. 